\title{
Experimental Investigation of Dewatering of Dairy Sludge by Pressure Filter Using Geotextile and Alum, Nano Particles for Sludge Conditioning
}

\author{
Sahil Mushtaq Mattoo, Vedant Shrivastava, Naveen Koshy Raji, Kapil Shankar Soni, \\ Pooja Deepak Pawar \\ Department of Civil Engineering, Bharati Vidyapeeth Deemed University College of Engineering, Pune, India \\ Email address: \\ pdpawar@bvucoep.edu.in (P. D. Pawar), sahilqwer@gmail.com (S. M. Mattoo), vedant284003@gmail.com (V. Shrivastava), \\ naveen.koshy97@gmail.com (N. K. Raji),kapilkmn@gmail.com (K. S. Soni)
}

\section{To cite this article:}

Sahil Mushtaq Mattoo, Vedant Shrivastava, Naveen Koshy Raji, Kapil Shankar Soni, Pooja Deepak Pawar. Experimental Investigation of Dewatering of Dairy Sludge by Pressure Filter Using Geotextile and Alum, Nano Particles for Sludge Conditioning. American Journal of Environmental Science and Engineering. Vol. 2, No. 2, 2018, pp. 26-31. doi: 10.11648/j.ajese.20180202.11

Received: May 8, 2018; Accepted: June 12, 2018; Published: July 6, 2018

\begin{abstract}
This paper presents the results of experimental work of dewatering by pressure filter using geotextile, aluminium sulphate and nanoparticles. In the present day, industries produce a lot of sludge for which open dumping is done, this causes several water borne diseases, bad odour, attraction of flies and land degradation. Sludge is the main cause for the former problems mentioned. In order to tackle these problems, dewatering of sludge was done by applying pressure and using geotextile, aluminium sulphate (as a sludge conditioning material), of dosages $550 \mathrm{mg} / 1,600 \mathrm{mg} / 1,650 \mathrm{mg} / 1$, nanoparticles (as a sludge conditioning material), of dosages $50 \mathrm{mg} / 1,60 \mathrm{mg} / 1,70 \mathrm{mg} / 1$. In this paper comparison is made, of filtrate by using just geotextile, aluminium sulphate $(6000 \mathrm{mg} / \mathrm{l})$ plus geotextile and nanoparticles $(50 \mathrm{mg} / \mathrm{l})$ plus geotextile. Results show that chemical characteristics such as TSS, TVS, TS, COD, BOD, $\mathrm{SO}_{4}$ has been reduced to $89.8 \%, 86.16 \%, 80.5 \%, 97.7 \%, 97.99 \%$, $82.12 \%$ respectively with aluminium sulphate and $92.4 \%, 87.5 \%, 81.4 \%, 97.8 \%, 98.06 \%, 98.06 \%, 86.25 \%$ respectively with nanoparticles, so the filtrate can be recycled and filter cake obtained after dewatering was tested for NPK, therefore it can be used as a fertilizer, thus proving zero waste conditioning.
\end{abstract}

Keywords: Geotextile, Aluminium Sulphate, Nanoparticles, Filter Cake, Sludge Conditioning

\section{Introduction}

The constituents removed in sludge treatment plants include screening, grit, scum and sludge. The sludge from waste water treatment operation and process is usually in the form of a liquid or semi solid liquid that typically contains from 0.25 to $12 \%$ solids by weight, depending on the operation and processes used. The problem of dealing with sludge is complicated because of biological treatment. Only a small amount of sludge contains solid matter.

Now a days the dewatering of waste water coming from industries are directly dumped into sludge drying beds in the open air which causes several water borne diseases, bad odour, attraction of flies and land degradation. Inspite of the use of sludge drying beds, here we are using geotextile, which in turn reduces the problems caused due to the use of sludge drying beds.
A Geotextile is an innovative and economical method for dewatering the digested bio-solids, dredge material sediments and industrial solid wastes, fly ash, coal ash slurry, lake and reservoir sediments, pulp and paper waste, dairy waste and sewage sludge.

Also, the addition of chemical dewatering accelerants and sludge conditioning agents like aluminium sulphate and nanoparticles can enhance the rate of dewatering significantly, and can trap contaminants within the dewatering waste.

\section{Chosing Geotextile for Dewatering Sludge}

After conducting several tests of geotextile by different scientists $([3,4,6,7])$, we could analyse that geotextile has: 
1. Good Filtration Efficiency

2. Reduction in the contained volume

3. Better effluent quality

4. Chemical conditioning of dredged sediment

5. Loss of solids

Geotextile Properties

Some of the commercially available geotextile types are:

1. woven monofilament

2. woven multifilament

3. woven slit-film monofilament

4. woven slit-film multifilament

5. non-woven continuous filament heat-bonded

6. non-woven continuous filament needle-punched

7. non-woven staple needle-punched

8. non-woven resin-bonded

9. other woven and non-woven combinations

From the following above types of geotextile, for performing Pressure Filter Test, woven polyester multifilament geotextile is selected. The woven geotextile was characterized for its mechanical and hydraulic properties as discussed below;

Thickness: The thickness of the woven geotextile was determined as per the guidelines provided by ASTMD5199 and the result obtained is $0.6675 \mathrm{~mm}$.

Mass per unit area: The mass $\left(\mathrm{gm} / \mathrm{m}^{2}\right)$ of the geotextile was determined as per the guidelines provided by ASTMD5261; the result obtained is $272.78 \mathrm{gm} / \mathrm{m}^{2}$ for woven polyester multifilament geotextile.

Mechanical Properties

Wide Width Strip Test

The wide width tensile strength and strain of the geotextile was determined as per the guidelines provided by ASTM D4595. The result obtained for woven polyester multifilament geotextile is strength $94.65 \mathrm{KN} / \mathrm{m}$, strain $=8 \%$ in machine direction and strength $=39.55 \mathrm{KN} / \mathrm{m}$, strain= $10 \%$ in cross machine direction.

Puncture Strength: The puncture strength of the geotextile was determined as per the guidelines provided by ASTM D4833. The result obtained for woven polyester multifilament geotextile is $0.66 \mathrm{KN}$.

Grab Strength: The grab strength of the geotextile was determined as per the guidelines provided by ASTM D4632. The result obtained for the woven polyester multifilament geotextile is strength $=0.94 \mathrm{KN} / \mathrm{m}$ in warp direction and strength $=0.56 \mathrm{KN} / \mathrm{m}$ in weft direction.

Hydraulic Properties

Permittivity: The permittivity of the geotextile was determined as per the guidelines provided by ASTM D4491. The result obtained for the woven polyester multifilament geotextile is permittivity $=0.037 \mathrm{~s}^{-1}$

Apparent Opening Size: The apparent opening size of the geotextile was determined as per the guidelines provided by ASTM D4751. The result obtained for the woven polyester multifilament geotextile is $\mathrm{AOS}<0.075 \mathrm{umm}$.

\section{Aluminium Sulphate as a Sludge Conditioning Material}

Aluminium sulphate is a type of chemical compound usually a hydrated double sulphate salt of aluminium with the general formula XAl $\left(\mathrm{SO}_{4}\right)_{2} 12 \mathrm{H}_{2} \mathrm{O}$, where $\mathrm{X}$ is mono valent cation such as potassium or ammonium.

Aluminium sulphate was used since middle ages as a sludge conditioning material to clarify turbid and waste liquids in tanning. Coagulation is the key step in sludge treatment process and is widely used to purify piped and sludge, in medicine, for cosmetics, food preparation and cloth.

In water purification, aluminium sulphate causes suspended impurities to coagulate into larger particles and then settle to the bottom of the container.

When dissolved in large amounts of slightly alkaline or neutral water, aluminium sulphate produces a gelatinous precipitate of aluminium hydroxide, $\mathrm{Al}(\mathrm{OH})_{3}$. The effectiveness of aluminium coagulants arises principally from their ability to form multi-charged polynuclear complexes with enhanced adsorption characteristics. The nature of complexes formed could be controlled by the $\mathrm{pH}$ of the system.

More specifically, aluminium sulphate works by neutralising the negative charge on suspended and colloidal particles to produce compact flocs suitable for easy removal by either settlement or flotation processes and promotes more efficient sludge digestion and dewatering.

\section{Nanoparticles for Dewatering}

Nanoparticles are sub-nanosized colloidal structures composed of synthetic or semi-synthetic polymers. Nano particles are particles between 1 and 100 nanometres in size with a surrounding interfacial layer (interior part of nano scale matter), fundamentally affecting all its properties. Nano filtration has low operating, energy costs and it increases the dewatering rate. It helps in the reduction of TDS, pesticides, VOC's, heavy metals, nitrates, sulphates, colour and turbidity.

Addition of nanoparticles modifies the structure of the sludge and provides benefits in terms of dewatering rate. The waste water samples dosed with nanoparticles exhibits faster water removal, a more permeable filter cake and hence more permeable sludge. A concentration of $2-4 \%$ of nanoparticles is required to achieve a noticeable change.

Polymers for nanoparticles:

1. Natural hydrfophilic polymers:

a) Proteins:-Gelatin, albumin, lectins, legumin.

b) Polysaccharides:- alginate, dextran, chitosan, agarose

2. Synthetic hydrophobic polymers:

c) Pre-polymerized polymers: - Poly (e-caprolactone) (PECL), poly (lactic acid) (PLA), polystyrene.

d) Polymerized in process polymers: - Poly (isobutyl cyanoacrylates ((PICA), poly (butyl cyano acrylates). 


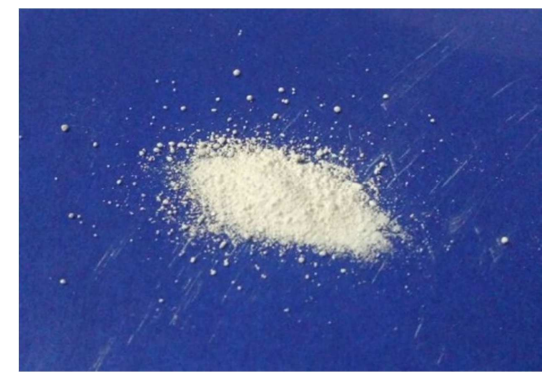

Figure 1. Nanoparticles.

\section{Application of Pressure}

Application of pressure increases the dewatering rate to a considerable level. Using a metal piston coated with synthetic rubber weighing roughly around $1.48 \mathrm{kgs}$ and additional weight of $1 \mathrm{~kg}$ is applied.

Total pressure applied on the waste water:

$\mathrm{P}=\mathrm{F} / \mathrm{A}$

$$
\begin{aligned}
& \text { Force }=23.324 \mathrm{~N} \\
& \text { Area }=0.0176 \mathrm{~m}^{2} \\
& \begin{aligned}
\mathrm{P} & =23.324 / 0.0176 \\
& =1.32 \mathrm{KN} / \mathrm{m}^{2}
\end{aligned}
\end{aligned}
$$

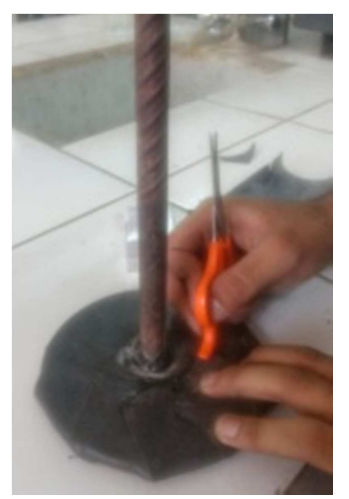

Figure 2. Metal piston coated with synthetic rubber.

\section{Selection of Dosages of Aluminium Sulphate and Nanoparticles}

The jar test has been widely used to determine the optimum coagulant dosage for removing turbidity by chemical pre-treatment. In this mixing apparatus was used to ensure identical mixing conditions in all tests.

For Aluminium Sulphate:

Selection of dosages of aluminium sulphatewas done through jar test, following dosages were used (in $500 \mathrm{ml}$ waste water):

\section{$1-550 \mathrm{mg} / 1$}

2- $600 \mathrm{mg} / 1$

3- $650 \mathrm{mg} / 1$

For 2 minutes, fast mixing was done, for 20 minutes, slow mixing was done, further it was kept for settlement for 20 minutes.

Turbidity obtained for the following dosages:

1- $550 \mathrm{mg} / 1: 15.0 \mathrm{NTU}$

2- $600 \mathrm{mg} / 1: 13.1 \mathrm{NTU}$

\section{3- $650 \mathrm{mg} / 1: 14.3 \mathrm{NTU}$}

Optimum turbidity obtained using Aluminium sulphate $=$ $13.1 \mathrm{NTU}$ in $500 \mathrm{ml}$ sample.

Therefore selected dosage of Aluminiumsulphate: $600 \mathrm{mg} / 1$ (for $500 \mathrm{ml} \mathrm{sample):} 6000 \mathrm{mg} / \mathrm{l}$ (for 5 litresof waste water)

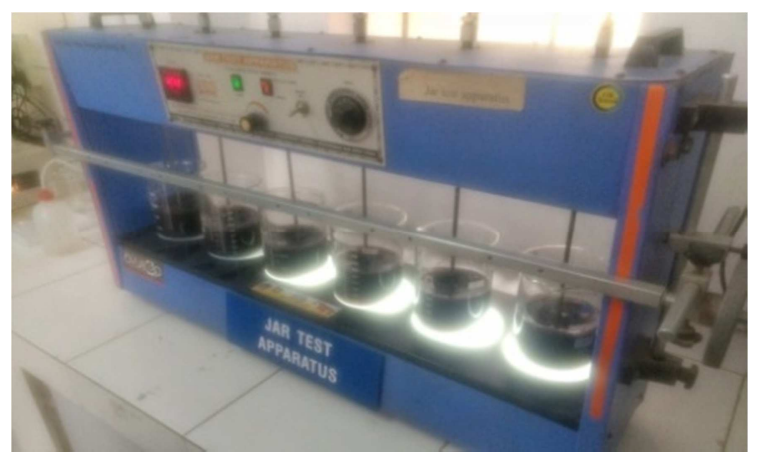

Figure 3. Jar test apparatus.

For Nanoparticles:

Similarly, for the selection of dosages of nanoparticles was done through jar test, following dosages were used:
$1-50 \mathrm{mg} / \mathrm{l}$
$2-60 \mathrm{mg} / 1$
$3-70 \mathrm{mg} / 1$

For 2 minutes, fast mixing was done, for 20 minutes, slow mixing was done, further it was kept for settlement for 20 minutes.

Turbidity obtained for the following dosages:

1- $50 \mathrm{mg} / \mathrm{l}: 12.2 \mathrm{NTU}$

2- $60 \mathrm{mg} / 1: 12.8 \mathrm{NTU}$

3- $70 \mathrm{mg} / \mathrm{l}: 11.8 \mathrm{NTU}$

Optimum turbidity obtained using Nanoparticles $=12.2$ NTU in $50 \mathrm{ml}$ sample

Therefore selected dosage of nanoparticles: $50 \mathrm{mg} / 1$ (for $500 \mathrm{ml}$ sample):

$500 \mathrm{mg} / 1$ (for 5 litres of waste water)

\section{Imhoff's Cone Analysis}

The Imhoff settling cone and rack is used to determine the volume of settleable solids from a known volume of waste. The sample may be fresh or saline water, or domestic or industrial waste water.

Itis useful method to determine the amount of solids entering a waste water treatment plant, also for estimating the amount of sludge to be expected during waste water treatment process. The total volume of solids in a sample is a combination of suspended and dissolved solids. Through Imhoff cone analysis we can only measure volume of suspended solids in a sample (in $\mathrm{mg} / \mathrm{l}$ ).

For Aluminium Sulphate:

Observations:

We have observed that the settlement came out to be 55 $\mathrm{mm}$.

Result:

SVI $=$ Settled sludge volume/MLSS 
$=55^{*} 1000 / 320$

$=171.8 \mathrm{mg} / \mathrm{l}$

Conclusion: The sludge is of very poor quality.

For Nanoparticles:

Observations:

We have observed that settlement came out to be $78 \mathrm{~mm}$. Result:

$$
\begin{aligned}
\text { SVI } & =\text { Settled Volume/MLSS } \\
& =78 * 1000 / 310 \\
& =251.6 \mathrm{mg} / 1
\end{aligned}
$$

Conclusion: The sludge is of very poor quality.

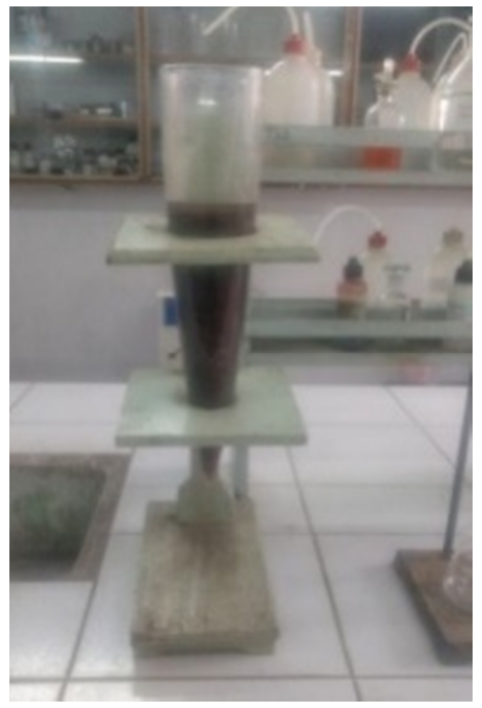

Figure 4. Imhoff cone analysis.

\section{Experimental Setup}

Scrap material of cast iron was used for the experimental setup. One flange was welded to the collection chamber, the other to the filtration chamber.

Three legged stand (made of cast iron) was welded at the bottom for stability of the setup.

Geotextile was provided in between the two flanges and tightened with bolts. The whole setup was painted with organic paint (greyish silver), also two handles were provided for easy mobility of the setup.

Dimensions of the setup:

Cylinder Diameter: $150 \mathrm{~mm}$

Height of CollectionChamber: $600 \mathrm{~mm}$

Height of FiltrationChamber: $300 \mathrm{~mm}$

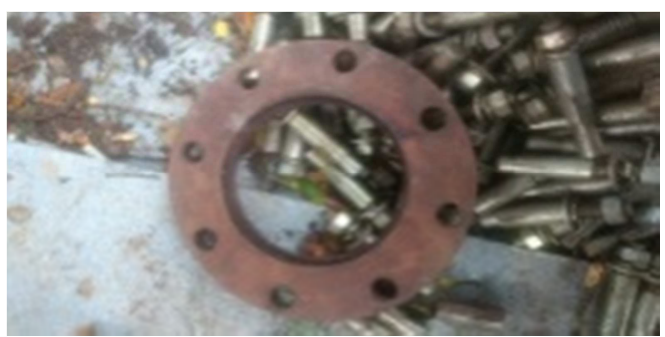

(a)

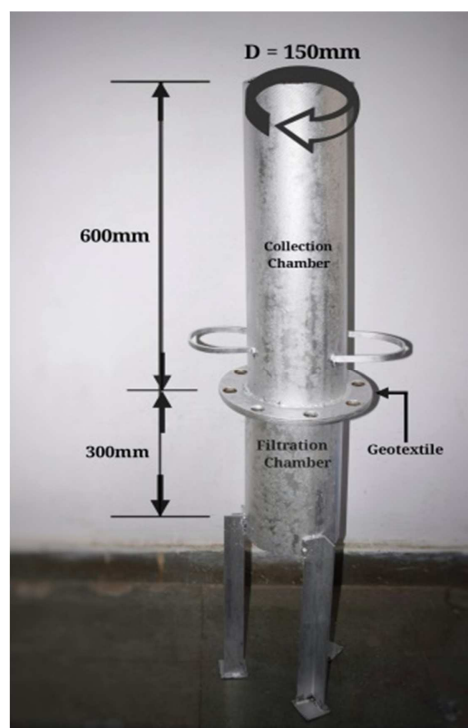

(b)

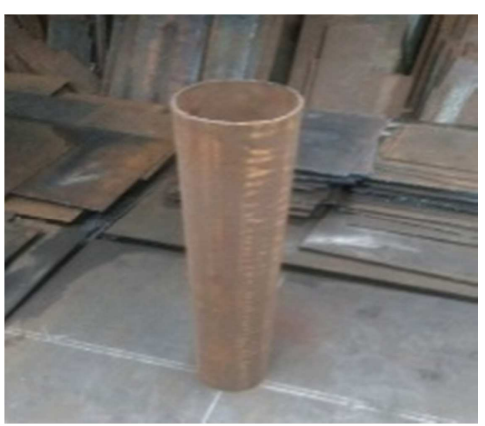

(c)

Figure 5. Experimental setup.

\section{Experimental Analysis}

Observation of amount of filtrate filtrated in different intervals of time:

Table 1. Through Geotextile.

\begin{tabular}{lll}
\hline Time (min) & Quantityofsample $(\mathbf{m l})$ & Discharge $\left(\mathbf{m}^{\mathbf{3}} / \mathbf{s}\right)\left(\mathbf{1 0}^{-\mathbf{6}}\right)$ \\
\hline 1 & 260 & 4.33 \\
5 & 400 & 1.33 \\
10 & 490 & 0.816 \\
20 & 550 & 0.458 \\
30 & 605 & 0.336 \\
60 & 740 & 0.2055 \\
90 & 810 & 0.15 \\
$24 \mathrm{hrs}$ & 1890 & 0.0218 \\
\hline
\end{tabular}

Table 2. Using Aluminium Sulphate.

\begin{tabular}{lll}
\hline Time (min) & Quantity of sample $(\mathbf{m l})$ & Discharge $\left(\mathbf{m}^{\mathbf{3}} / \mathbf{s}\right)\left(\mathbf{1 0}^{\mathbf{- 6}}\right)$ \\
\hline 1 & 410 & 6.83 \\
5 & 525 & 1.75 \\
10 & 650 & 1.083 \\
20 & 750 & 0.625 \\
30 & 845 & 0.47 \\
60 & 1020 & 0.28 \\
90 & 1100 & 0.203 \\
$24 \mathrm{hrs}$ & 2700 & 0.0312 \\
\hline
\end{tabular}


Table 3. Using nanoparticles.

\begin{tabular}{lll}
\hline Time (min) & Quantity of sample $(\mathbf{m l})$ & Discharge $\left(\mathbf{m}^{\mathbf{3}} / \mathbf{s}\right)\left(\mathbf{1 0}^{\mathbf{6}}\right)$ \\
\hline 1 & 490 & 8.6 \\
5 & 490 & 2.3422 \\
10 & 670 & 1.33 \\
20 & 800 & 0.754 \\
30 & 905 & 0.538 \\
60 & 970 & 0.309 \\
90 & 1115 & 0.226 \\
$24 \mathrm{hrs}$ & 1220 & 0.0416 \\
\hline
\end{tabular}

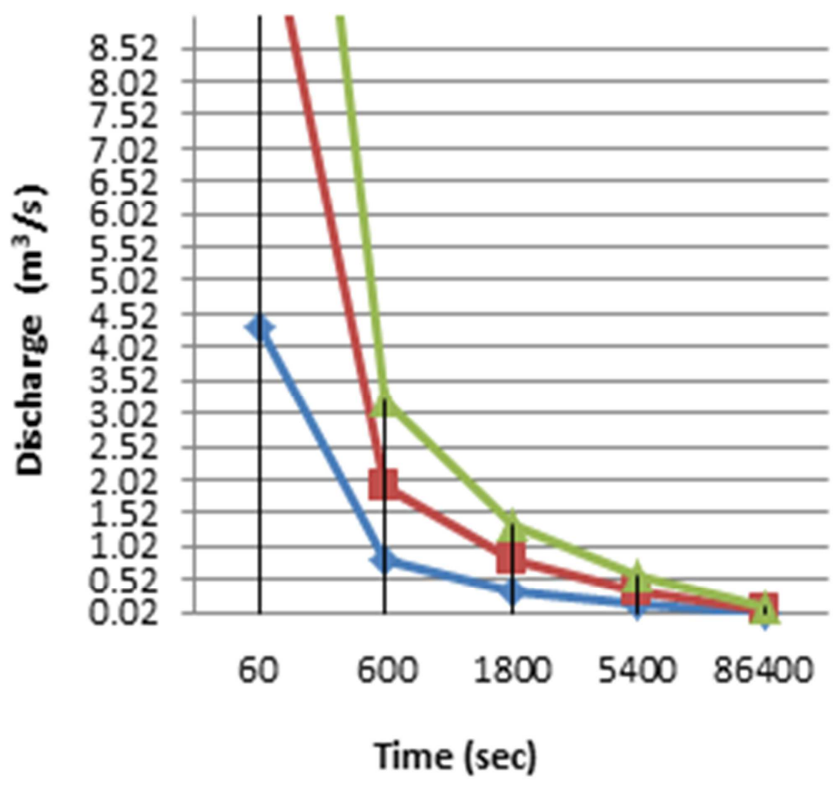

Figure 6. Discharge v/s Time graph.

- Through Geotextile.

_Using Aluminium sulphate.

_Using Nano Particles.

The above graph demonstrates the discharge of waste water of 3 different samples in different intervals of time.

Experimental Resluts

First, by directly passing dairy sludge (sample 1) through geotextile, the filtrate was collected.

Further, aluminium sulphate as a conditioning agent was added to dairy sludge (sample 2) and the filtrate was collected.

At last, nanoparticles were added to dairy sludge (sample 3) and filtrate was collected. Following are the tests conducted on dairy sludge (3 samples) with their results:

Table 4. Chemical characteristics test results.

\begin{tabular}{llllll}
\hline Sr. no & Description & Direct Sample & Using Geotextile & Using Geotextile With Aluminium Sulphate & Using Geotextile With neon-particle \\
\hline 1 & pH & 8.25 & 8.36 & 8.28 & 8.45 \\
2 & TSS (mg/lit) & 1625 & 138 & 165 & 125 \\
3 & TVS (mg/lit) & 289 & 51 & 40 & 36 \\
4 & TS (mg/lit) & 7245 & 1612 & 1410 & 1345 \\
5 & $\mathrm{COD}(\mathrm{mg} /$ lit) & 7808 & 160 & 179.2 & 172.8 \\
6 & $\mathrm{BOD}(\mathrm{mg} / \mathrm{lit})$ & 3003 & 61.5 & 60.1 & 58.5 \\
7 & $\mathrm{SO}_{4}(\mathrm{mg} / \mathrm{lit})$ & 40 & 6.5 & 7.15 & 4.1 \\
8 & Chlorine & 0.2 & 0.1 & 0.1 & 0.1 \\
\hline
\end{tabular}

Filter cake properties without adding alum: $\mathrm{pH}=7.8$

Moisture content $=72.6 \%$

Phosphates $=19.05 \mathrm{mg} / 1$

Nitrogen $=29.96 \mathrm{mg} / \mathrm{l}$
Specific gravity $=1.06$

Dry density $=0.560$ 


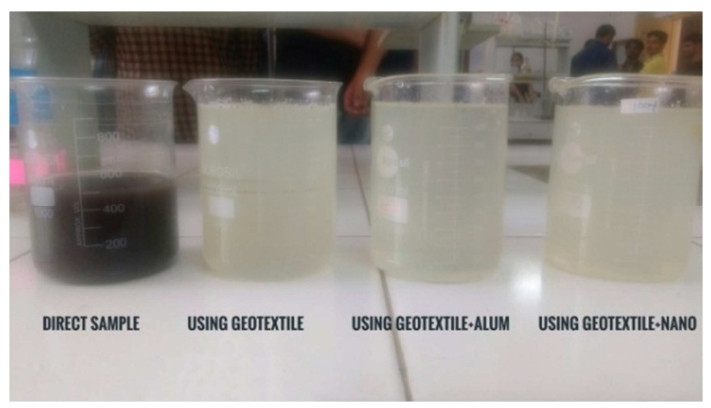

Figure 7. Comparison of different samples.

\section{Conclusion}

In case of woven polyester multifilament geotextile for Katraj dairy sludge with adding nano particles as sludge conditioning shows more discharge as compared to Katraj dairy sludge with addition of alum we can conclude that. Discharge rate is significantly affected due to the addition of nano material. After experimental analysis we have observed that by using Aluminium Sulphate as a conditioning agent, dewatering rate subsequently increased, also the chemical characteristics decreased, which are as TSS: $89.8 \%$, TVS: $86.16 \%$, TS: $80.5 \%$, COD: $97.7 \%$, BOD: $97.99 \%, \mathrm{SO}_{4}$ : $82.125 \%$ removal. Further we observed that, after using Nanoparticles as a coagulant, dewatering rate further increased, also the chemical characteristics further decreased, TSS: $92.4 \%$, TVS: $87.5 \%$, TS: $81.4 \%$, COD: $97.8 \%$, BOD: $98.06 \%, \mathrm{SO}_{4}: 86.25 \%$. The filter cake obtained can be used as a fertilizer based on the traces of Nitrogen, Potassium Phosphate found in it, thus proving zero waste conditioning.

\section{References}

[1] Das, N. K., Mandal, J. N. and Rathanlal, R. B. (2013). "Experimental, Environmental and Finite Element Analysis of the Woven Polyster Geotextile Tube". EJGE vol18, Bund. C, pp 577-587.

[2] Das, N. K. and Mandal, J. N. (2012). "Experimental, Environmental and Finite Element Analysis of Woven Jute Geotextile Tube”.

[3] Fowler, J., Duke, M., Schmidt, M. L., Crabtree, B., Bagby, R. M. \& Trainer, E. (2002). "Dewatering sewage sludge and hazardous sludge with geotextile tubes", Proceedings of $7^{\text {th }}$ Int. Conf. on Geosynthetics, Vol. 3, Nice, France, 1007-1012

[4] Gaffney, D. A., Chambers, M., Fatheringham, C. and Minoz, R. (2011). "The value of chemical conditioning with geotextlie tube dewatering". Geo-Frontiers $\bigodot$ ASCE, pp 2152-2162.

[5] Huang, W. and Koerner, R. M. (2005) "An Amendment Strategy for Enhancing the Performance of Geotextile Tubes Used in Decontamination of Polluted Sediments and Sludge's", Proceedings of the Sessions of the Geo-Frontiers.

[6] Koerner, R. M. (1999). "Designing with Geosynthetics". 4th Edition, Prentice Hall, NJ.

[7] Lawson, C. R. (2008). "Geotextile Containment for Hydraulic and Environmental Engineering." Geosynthetics International,

\section{$15,6,384-427$}

[8] Moo-Young, H. K., Douglas, A. G. and Xinghua, Mo. (2002). "Testing Procedures to Assess the Viability of Dewatering with Geotextile Tubes.", Geotextiles and Geomemebranes, 20 , 5, 289-303

[9] Torbern Bergman (1767), "IX. De confectioneAluminis". In Opusculaphysicaetchemica, I. G. Müller, Leipzig, 1788), volume 1. On pp. 306-307, after noting that Marggraf had noticed that potash caused alum to crystallize from a solution of alumina and sulfuric acid, Bergman adds "Notatuquoquedignumest, quod hoc cristallisation is obstaculumal calivolatilia equetollatur, non vero alkali minerali et calce." (It is significant as well that by [use of] the volatile alkali [i.e., ammonia] this obstacle to crystallization is similarly removed, but not [in the cases of] mineral alkali [i.e., sodium carbonate] and lime.)

[10] A. J. Hall \& E. Photos-Jones "The nature of Melian alumen and its potential for exploitation in Antiquity" in Bogard.

[11] Andreas Sigismund Marggraf (1754) (Experiments made on the earth of alum).

[12] Bell, Chichester H. (1887). Summarizing original article by C. Fabre (Compt. rend, 105, 114-115). "Selenium Alums". Abstracts of chemical papers. Inorganic chemistry. Journal of the Chemical Society. Volume LII. Part II: 1014. Retrieved 2017-08-19.

[13] Chisholm, Hugh, ed. (1911). "Alum". Encyclopædia Britannica. 1 (11th ed.). Cambridge University Press. pp. 766-767.

[14] Batista, Carlos A. Silvera; Larson, Ronald G.; Kotov, Nicholas A. (2015-10-09). "Nonadditivity of nanoparticle interactions". Science. 350 (6257): 1242477.

[15] Kiss, L. B.; Söderlund, J.; Niklasson, G. A.; Granqvist, C. G. (1999). "New approach to the origin of lognormal size distributions of nanoparticles". Nanotechnology. 10: 25-28

[16] Buzea, C.; Pacheco, I. I.; Robbie, K. (2007). "Nanomaterials and nanoparticles: Sources and toxicity". Biointerphases. 2 (4): MR17-MR71

[17] Gubin, Sergey P. (2009). Magnetic nanoparticles. Wiley-VCH. ISBN 3-527-40790-1.

[18] Zoroddu, M. A.; Medici, S.; Ledda, A.; Nurchi, V. M.; Lachowicz, J. \& Peana, M. (2014). "Toxicity of nanoparticles". Curr Med Chem. 21 (33): 3837-53.

[19] Sung, KM; Mosley, DW; Peelle, BR; Zhang, S; Jacobson, JM (2004). "Synthesis of monofunctionalized gold nanoparticles by fmoc solid-phase reactions". Journal of the American Chemical Society. 126 (16): 5064-5

[20] Stefan, C. and Cantre, S. (2006). "Estimation the dewatering time in geosynthetic tube dewatering projects". Proceedings of 8th International Conferenenceon Geosynthetics, Sep 18-22, Yokohama, Japan., Kuwani\&Koseki, J (eds), Millpress, Rotterdam, ISBN 9059660447

[21] Torre, M. and Timpson C. (2011). Development and evolution of key industry dewatering tests (HBT, Cone, RDT, GDT) and Accuracy in predicting full scale results. pp 2194-2202.

[22] U. S. EPA (2008). "Dredged Material Management Program".

[23] Yee, T. W., Lawson, C. R., Wang, Z. Y., Ding, L. and Liu, Y. (2012). "Geotextile tube of dewatering of contaminated sediments, Tianjin Eco-City, China". Geotextiles and Geomembranes 31, pp 39-50. 